\title{
Examining the Soils Adjacent to the Historical Pitch Lake for Levels of Polycyclic Aromatic Hydrocarbons (Pahs) and Naturally Occurring Pah-Degrading Bacteria
}

\section{Amalia Hosein ${ }^{1}$, Azad Mohammed², Pathmanathan Umaharan², Adesh Ramsubhag ${ }^{2}$}

${ }^{1}$ The Biomedical Engineering Unit, University of Trinidad and Tobago, Trinidad and Tobago

${ }^{2}$ Department of Life Sciences, Faculty of Science and Agriculture, University of the West Indies, St. Augustine amaliahosein@gmail.com

Abstract: The soils adjacent to the La Brea Pitch Lake in Trinidadare expected to have high levels of Polycyclic Aromatic Hydrocarbons (PAHs) and PAH-degrading bacteria. This is due to the historical influx of hydrocarbons (bitumen) since the Cretaceous period. The PAHs are toxic, carcinogenic and genotoxic compounds which are natural components found in bitumen and natural oil seepages. This study investigates the occurrence of five selected PAHs (viz. naphthalene, acenaphthene, anthracene, phenanthrene and pyrene) andthe presence of bacteria that can utilize these selected PAH in soils neighbouring the PitchLake. To do this, soil samples from three distance zones to the perimeter of the Pitch Lake (zone 1: within $200 \mathrm{~m}$; zone 2: within 400m and zone 3: $>500 \mathrm{~m}$ ) were analyzed for levels of five selected and screened for their degrading bacteria using selective enrichment procedures. The results showed that the levels of these individual PAHs were generally above the standard acceptable limit of $1 \mathrm{mg} / \mathrm{Kg}$ among all 3 zones except for anthracene in Zone 2 . The levels of the total PAHs ( $\sum 5$ PAHs) showed a general trend of decreasing concentrations with high variability as thedistance from the Pitch Lake increased.The results of the soils screened for potential PAH-degrading bacteria showed that isolates in zone 1 and 2 (HIS) produced more PAH degraders for the more recalcitrant PAHs (viz. phenanthrene, anthracene,and pyrene) compared to naphthalene and acenaphthene, which bothappeared independent of zones.

Keywords: Polycyclic aromatic hydrocarbons (PAHs), naphthalene, acenaphthene, anthracene, phenanthrene, pyrene, PAH-degrading bacteria, La Brea Pitch Lake

\section{INTRODUCTION}

Polycyclic Aromatic Hydrocarbons (PAHs) exhibit carcinogenic and/or mutagenic properties and these are listed by the United States Environmental Protection Agency (US EPA) and European Commission (EC) as priority pollutants (Amellal et al., 2001). The European standards for PAHs in soils, sediments, and groundwater has been well documented and evaluated in recent years (Lijzen et al., 2001) and will be used as the baseline for purposes of this research. Utilizing the revised clean up standards for an average soil for the Netherlands (10\% organic matter and $25 \%$ clay) should range between $1-40 \mathrm{mg}(\mathrm{PAH}) / \mathrm{Kg} \mathrm{dw}$, if it is greater than $40 \mathrm{mg}(\mathrm{PAH}) / \mathrm{Kg}$ $\mathrm{dw}$, then remediation should be undertaken(Harmsen, 2004). Generally in the natural terrestrial environment from biological processes, soils are estimated to have levels of 1-100 $\mathrm{gg} / \mathrm{Kg}$ PAHs (Wilcke, 2000), whereas concentrations of PAHs in highly polluted soils can range anywhere from $10 \mathrm{mg} / \mathrm{Kg}$ to $10 \mathrm{~g} / \mathrm{Kg}$ dry weight (Stieber et al., 1994).

In Trinidad, the health of the environment is of grave concern due to the continuous influx of contaminants through oil spills or by-products of factory processes. Although legal requirements for monitoring and controlling these contaminants are stipulated within the Environmental Management Agency Act (2002), the Act only requires a reduction of Total Petroleum Hydrocarbons (TPH) to be less than $10 \mathrm{mgL}-1$. However, 
Examining the Soils Adjacent to the Historical Pitch Lake for Levels of Polycyclic Aromatic Hydrocarbons (Pahs) and Naturally Occurring Pah-Degrading Bacteria

studies have shown that during remediation processes the structurally simple compounds are degraded rapidly whereas complex compounds such as the PAHs tends to be recalcitrant to degradation (Mueller et al., 1996). Thus, although the TPH levels maybe within the stipulated levels, PAHs and other recalcitrant compounds can be relatively high(Cerniglia, 1992; Lehmann, 1998).

The La Brea Pitch Lake is one of the three largest natural petroleum seepages in the world(Mohammed \& Agard, 2004). It is located on the southwestern coast of the island of Trinidad and measures approximately 41

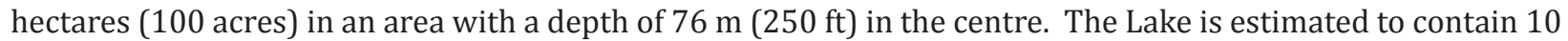
million tons of natural asphalt, referred to locally as pitch, which contains a plethora of hydrocarbons (LATT, 2004). Considering that the Lake has been in existence since the Cretaceous period(Kugler, 1965), there is limited information on possible influences of the Pitch Lake on its surrounding terrestrial environment.

To our knowledge, this is the first study done on PAH levels in the soils of Trinidad. The aim of this study is to establish baseline levels of selected PAHs in the soils adjacent to the La Brea Pitch Lake and explore their potential, as sources of selected PAH-degrading bacteria.

\section{Materials AND Methods}

\section{Sample Site}

Three zones along a distance gradient adjacent to the southern perimeter of the La Brea Pitch were taken sampled (see Figure 1). The study zones were situated within 200m (zone 1), within 200 - 400 m (zone 2) and more than $500 \mathrm{~m}$ (zone 3 and the reference site) from the southern perimeter of the La Brea Pitch Lake in the island of Trinidad.Triplicate core samples of soil at a depth of 8-10 $\mathrm{cm}$ (approximately $100 \mathrm{~g}$ each) were taken per quadrant. Samples were transported on ice-cooled containers, stored at $0^{\circ} \mathrm{C}$ until analysis could be performed.

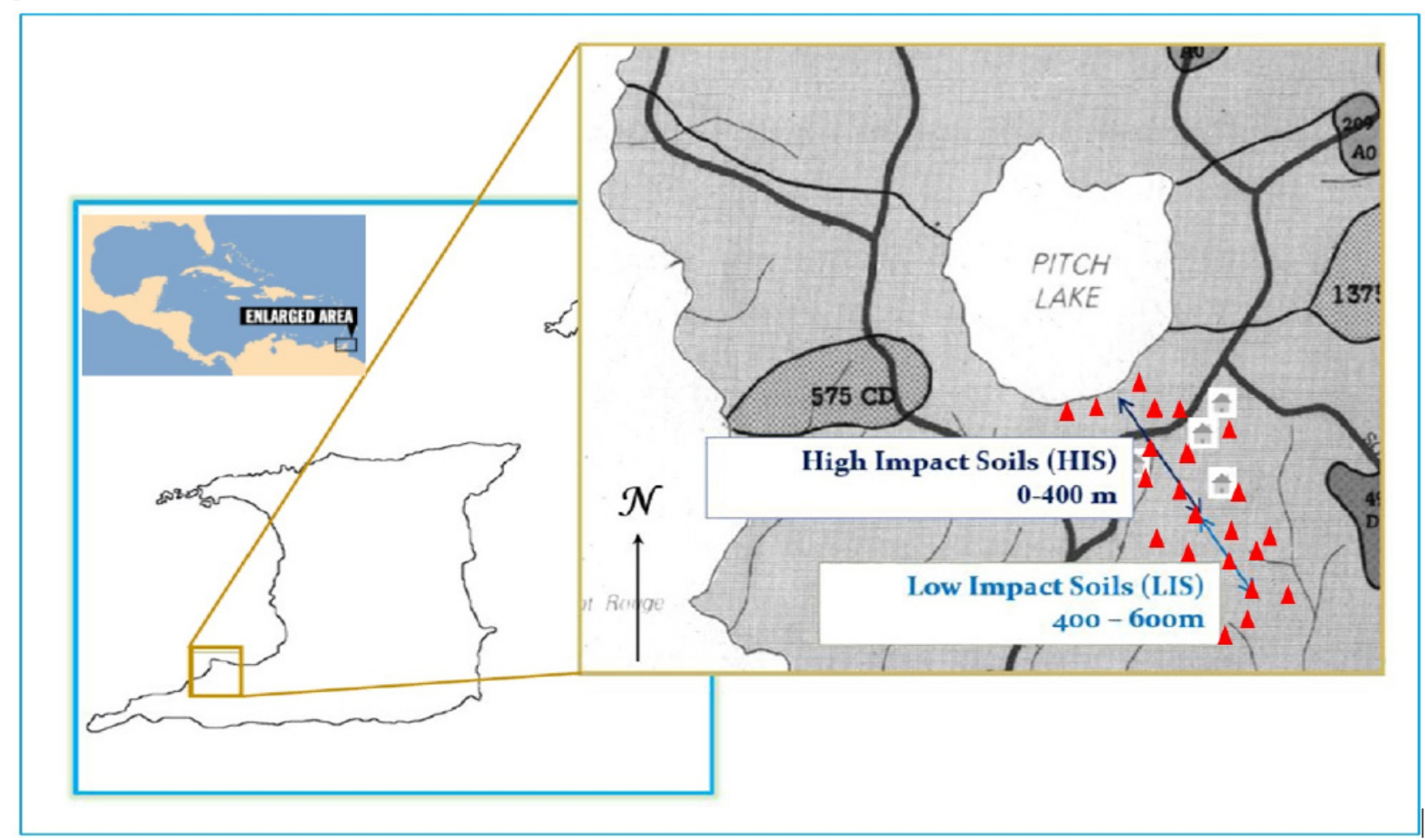

Fig1. Location of sample site, impact zones and distribution of sampling points 
Examining the Soils Adjacent to the Historical Pitch Lake for Levels of Polycyclic Aromatic Hydrocarbons (Pahs) and Naturally Occurring Pah-Degrading Bacteria

\section{PAH Extraction, Purification and Analysis}

Soxhlet extractions of PAHs were conducted using hexane as the solvent(ECRC, 2003). This involved weighing approximately $5 \mathrm{~g}$ of each soil into a porous cellulose ( $94 \mathrm{~mm}$ external length by $33 \mathrm{~mm}$ internal diameter) Whatman thimble and then extracting the PAHs in the soil using a Soxhlet apparatus consisting of a $500 \mathrm{~mL}$ round-bottomed flask, a condenser and extractor tube, seated in a temperature-controlled heating mantle. Extractions were done at $55-60^{\circ} \mathrm{C}$ for 8 hours with $120 \mathrm{~mL}$ hexane solvent.

Sample extracts were reduced to approximately $1 \mathrm{~mL}$ and added to an assembled chromatography column $(1 \mathrm{~cm}$ diameter with $25 \mathrm{~mL}$ total volume). The column consisted of a wad of glass wool ( $\sim 1 \mathrm{~cm}$ thick), approximately $1 \mathrm{~cm}$ of sodium sulphate, $5 \mathrm{~g} \mathrm{KOH}$-modified silica gel and another $1 \mathrm{~cm}$ of sodium sulphate were added to the column in that order. The column was then immediately saturated with approximately $25 \mathrm{~mL}$ of hexane. A $125 \mathrm{~mL}$ collection flask was placed beneath each column which contained approximately $2 \mathrm{~g}$ of copper filings activated with concentrated nitric acid to remove organic acids and residual sulphur.The entire $1 \mathrm{~mL}$ sample extract was added to the column and the residue from the sample vial was rinsed sequentially three times with 1-2 $\mathrm{mL}$ of $5 \%$ dichloromethane in hexane solvent which was also added to the column. The PAHs were then eluted with $40 \mathrm{~mL}$ of $5 \%$ dichloromethane in hexane and collected in the $125 \mathrm{~mL}$ glass beakers. The solvent containing the PAHs were then reduced to $0.5 \mathrm{~mL}$ by evaporating with nitrogen gas. Tubes were stored under refrigeration conditions $\left(0-4^{\circ} \mathrm{C}\right)$ until GC-MS analysis.The $0.5 \mathrm{~mL}$ extracts were shot into a PE Claris Gold Gas Chromatograph coupled with a 500 Turbomass mass selective detector (GC-MS). The column used for GC was PE 5 MS capillary column with a length of $25 \mathrm{~m}, 0.2 \mathrm{~mm}$ i.d., $0.33 \mathrm{~mm}$ film thickness (Perkin Elmer, Waltham, Massachusetts, USA). The conditions for analysis are seen in Table 1. Five PAHs (viz. naphthalene, acenaphthene, anthracene, phenanthrene,and pyrene) were selected based on their relatively low tetratoxicity (Mueller et al., 1997). The GC-MS chromatographs were used to quantify the levels of naphthalene, acenaphthene, anthracene, phenanthrene,and pyrene. A standard solution of the five priority PAHs were prepared for analysis. PAH concentrations were calculated on a dry weight basis. The limits of detection were $0.01 \mathrm{mg} / \mathrm{Kg}$ for the PAHs tested.

Table1. GC-MS program used in the analysis of five selected PAHs for the Pitch Lake impacted soils of La Brea

\begin{tabular}{|l|l|l|}
\hline \multicolumn{2}{|l|}{ GC/MS: Perkin Elmer Clarus 500} & \\
\hline Column: PE Elite 5 & & \\
\hline Carrier Gas: Helium & & \\
\hline Splitless:1:10 & Delay \\
\hline Oven Temperature Program (28:33min) & Hold for 3:00 min & \\
\hline \multicolumn{4}{|l|}{ Temperature } & Hold for 5:00 min & \\
\hline Initial Temperature & $75^{\circ}$ & \\
\hline Ramp 1 & $12^{\circ} /$ min to $300^{\circ}$ &
\end{tabular}

\section{Culture Conditions}

A basal salt medium (BSM) was prepared for enrichment and isolation of PAH-degrading bacteria based on a modification of the method described by Juhasz et al. (1997). The BSM contained ( $\left.\mathrm{L}^{-1}\right): 0.4 \mathrm{~g} \mathrm{~K}_{2} \mathrm{HPO}_{4} ; 0.4 \mathrm{~g}$ $\mathrm{KH}_{2} \mathrm{PO} 4 ; 0.4 \mathrm{~g}\left(\mathrm{NH}_{4}\right)_{2} \mathrm{SO} 4 ; 0.3 \mathrm{~g} \mathrm{NaCI} ; 5 \mathrm{~mL}$ trace element solution $\left(\mathrm{L}^{-1}: 400 \mathrm{mg} \mathrm{FeSO} \mathrm{H}_{4} \cdot 7 \mathrm{H}_{2} \mathrm{O}, 400 \mathrm{mg} \mathrm{MnSO} \mathrm{H}_{4} 4 \mathrm{H}_{2} \mathrm{O}\right.$, 
Examining the Soils Adjacent to the Historical Pitch Lake for Levels of Polycyclic Aromatic Hydrocarbons (Pahs) and Naturally Occurring Pah-Degrading Bacteria

$200 \mathrm{mg} \mathrm{ZnSO} \cdot .7 \mathrm{H}_{2} \mathrm{O}, 40 \mathrm{mg} \mathrm{CuSO}_{4} \cdot 5 \mathrm{H}_{2} \mathrm{O}, 300 \mathrm{mg} \mathrm{KI}, 50 \mathrm{mg} \mathrm{Na}_{2} \mathrm{MoO}_{4} \cdot 2 \mathrm{H}_{2} \mathrm{O}$;); $5 \mathrm{~mL}$ of Difco yeast extract solution $\left(5 \mathrm{~g} \mathrm{~L}^{-1}\right)$ and $5 \mathrm{~mL}$ of magnesium and calcium solution $\left(0.4 \mathrm{~g} \mathrm{MgSO}_{4} \cdot 7 \mathrm{H}_{2} \mathrm{O}\right.$ and $0.4 \mathrm{~g} \mathrm{CaCl}_{2} \cdot 2 \mathrm{H}_{2} \mathrm{O}$ in $\left.1 \mathrm{~L}\right)$. Trace elements, yeast extract,and magnesium/calcium solutions were sterilised by filtration ( $0.22 \mu \mathrm{m}$, Millipore $)$ and added to BSM after autoclaving at $121^{\circ} \mathrm{C}$ and 15 psi for 15 minutes. Stock solutions of each PAH were prepared in acetone at the following concentrations: $10 \mathrm{mg} \mathrm{mL}^{-1}$, naphthalene (NAP), acenaphthene (ACE), phenanthrene (PHE) and pyrene (PYR); and $5 \mathrm{mg} \mathrm{mL}^{-1}$ for anthracene (ANT). BSM was supplemented with individual PAHs to achieve a final concentration of $100 \mathrm{mg} \mathrm{L}^{-1}$. When used in plates BSM media was solidified with $1.5 \%$ bacto agar. Naphthalene, acenaphthene, anthracene, phenanthrene, and pyrene were purchased from Sigma Chemicals Co. (St. Louis, MO). Bacterial media components and reagents were purchased from Voigt Global Distribution Co. (Kansas City, MO) and Oxoid (Hamshire, UK). All solvents and chemicals used were high purity grade reagents.

\section{Bacterial inoculum}

Two sets of bacterial inoculum were used in this study. They were obtained by grouping soil samples taken from the soil surrounding the La Brea Pitch Lake. The first setincluded homogenized soil samples from zones 1 and 2 and wasreferred to as the High Impact Soils (HIS) since they were the closest to the PitchLake. The second setincluded homogenized soil samples from zone 3 and werereferred to as the Low Impact Soils (LIS) since they were the most distant from the PitchLake. The bacterial inoculum for each sample was prepared from $20 \mathrm{~g}$ soil (wet weight) which was shaken for 24 hours in $100 \mathrm{~mL}$ of Ringer's solution at $30^{\circ} \mathrm{C}$ and $175 \mathrm{rev}$ $\min ^{-1}$ (modified after Juhasz et al., 1997).

\section{Determination of total viable counts for PAH degraders}

For the soil sets (HIS and LIS), the total viable counts of bacteria capable of degrading the five PAH compounds (NAP, ACE, ANT, PHE and PYR) were determined by inoculating BSM plates amended with individual PAHs and observing for the appearance of "clear zones"(Kiyohara et al., 1982). The BSM agar plates were overlayed with $20 \mu \mathrm{L}$ of a single PAH $(100 \mathrm{mg} / \mathrm{mL}$ acetone) followed by spreading $0.1 \mathrm{~mL}$ bacterial (soil) suspension on the surface of plates. The plates were then incubated at $30^{\circ} \mathrm{C}$ and the numbers of "clear zones" appearing on plates were recorded every 2 days for 22 days. Tests were performed in triplicate.

\section{Data Analysis}

ANOVAs and correlations analysis was performed on Minitab 14 to determine differences of physicochemical parameters among Zones and the level of association between the various parameters.

\section{RESULTS AND DISCUSSION}

Although not significant, there was a general decrease in the levels of total PAH as the distance from the PitchLake increased. The reference zone (i.e. Zone 3), was expected to have levels of PAHs below the acceptable limit (i.e. $1 \mathrm{ppm}$ for individual and $40 \mathrm{ppm}$ for total PAHs), however as the results showed, Zone 3 located more than $500 \mathrm{~m} \mathrm{SW}$ from the perimeter of the Pitch Lake possessed levels above the acceptable limits (Table 2). With respect to individual PAHs, there were significantly lower levels of NAP in Zone 3 compared to Zones 1 and 2 and a decreasing trend (not significant) for ACE, ANT,and PHE. These results suggest that the Pitch Lake had an effect on the soil PAH levels and conform with the findings of (Mohammed, 2000)who reported higher levels of PAHs in coastal sediments closer to the pitch lake as compared to more distant areas. The lack of significant differences among Zones is considered as a result the nature of the Pitch Lake, which according to(Chaitan \& V.R.Graterol, 1992), possesses a network of pitch dykes or "veins" that can emerge at any random point outside the basin of Pitch Lake. 
Examining the Soils Adjacent to the Historical Pitch Lake for Levels of Polycyclic Aromatic Hydrocarbons (Pahs) and Naturally Occurring Pah-Degrading Bacteria

Table2. Mean and data range of selected PAHs $(\mathrm{mg} / \mathrm{kg} \mathrm{dw})$ in the soil samples from three different distance zones from the La BreaPitchLake.

\begin{tabular}{|l|c|c|c|c|c|c|c|}
\hline \multirow{2}{*}{ PAH (mg/kg) } & \multicolumn{2}{|c|}{ Zone 1 } & \multicolumn{2}{c|}{ Zone 2 } & \multicolumn{2}{c|}{ Zone 3 } \\
\cline { 2 - 8 } & Mean & Range & & Mean & Range & Mean & Range \\
\hline NAP & $36.6 \pm 3.57$ & $16.0-54.0$ & & $35.9 \pm 2.67$ & $23.8-51.0$ & $18.8 \pm 2.34$ & $13.2-28.3$ \\
\hline ACE & $9.2 \pm 2.70$ & ND -26.0 & & $7.9 \pm 1.13$ & ND -14.4 & $2.4 \pm 1.74$ & $0.0-10.5$ \\
\hline PHE & $10.8 \pm 3.29$ & ND -29.0 & & $11.1 \pm 1.94$ & ND -25.4 & $9.9 \pm 0.63$ & $8.0-12.1$ \\
\hline ANT & $5.5 \pm 2.76$ & ND - 20.2 & & $0.6 \pm 0.43$ & ND - 5.0 & $1.0 \pm 1.00$ & $0.0-6.0$ \\
\hline PYR & $2.5 \pm 2.52$ & ND - 22.7 & & ND & ND & $5.8 \pm 2.64$ & $0.0-14.0$ \\
\hline $\mathbf{\Sigma} 5$ PAHs & $60.4 \pm 11.49$ & $16.0-127.4$ & & $52.8 \pm 3.59$ & $30.7-74.4$ & $7.9 \pm 3.19$ & $27.2-49.3$ \\
\hline
\end{tabular}

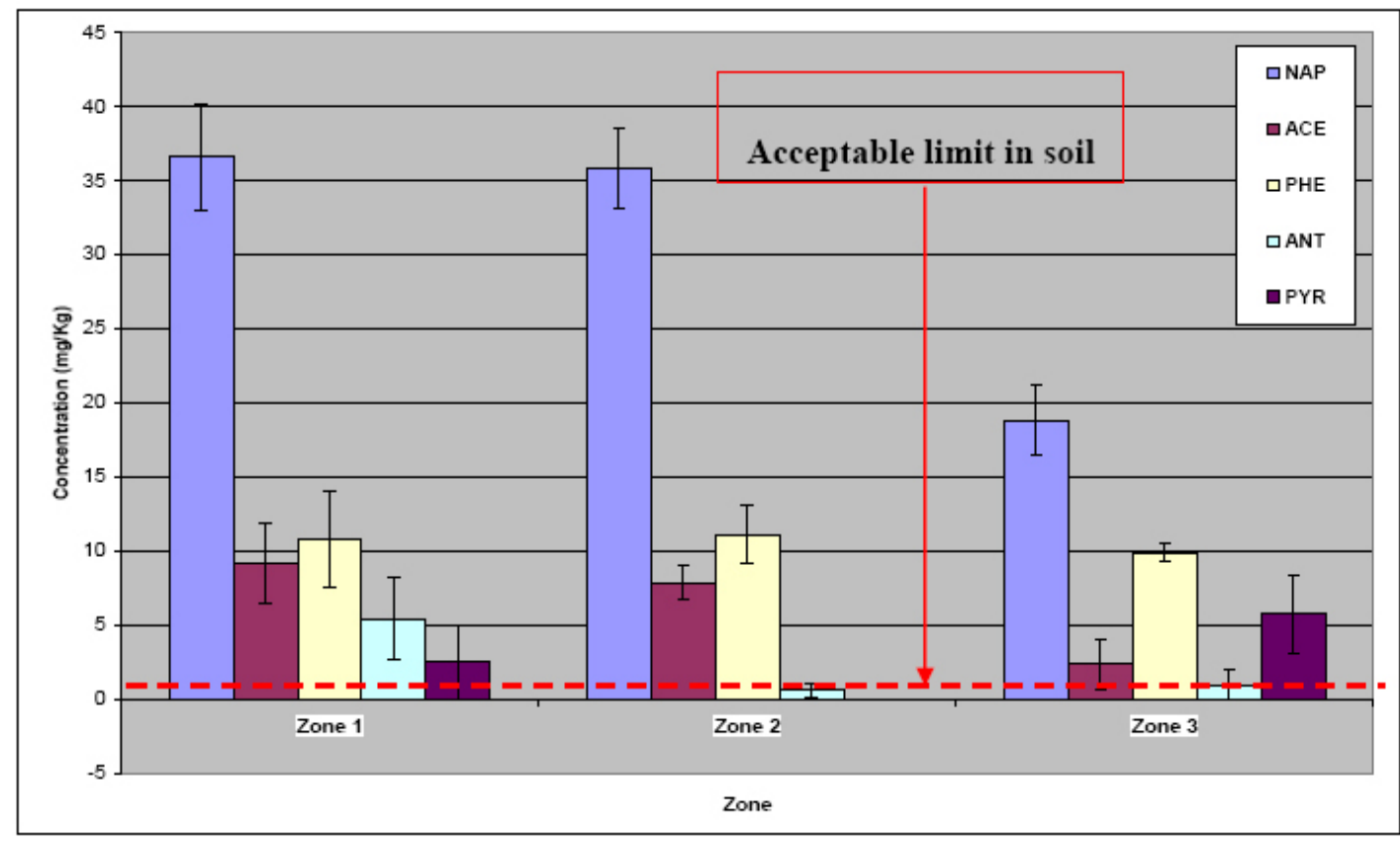

Red dashed line indicates acceptable limits in soil (1 ppm).

Keys: NAP: naphthalene, ACE: acenaphthene, PHE: phenanthrene, ANT: anthracene, PYR: pyrene, $(n=30)$

Fig2. Distribution of five of the selected PAHs ( $\mathrm{mg} / \mathrm{Kg} \mathrm{dw}$ soil) along a distance gradient from the La Brea Pitch Lake

There is limited published data on PAH levels in natural soils in Tropical regions. Findings from one study by (Wilcke et al., 2003)reported total levels of the same five PAHs (NAP, ACE, ANT, PHE \& PYR) to be $0.145 \mathrm{mg} /$ Kg in soils of the Amazon Basin, Brazil (Table 3). This is relatively low compared to soils surrounding the La Brea Pitch Lake which had total levels up to $127 \mathrm{mg} / \mathrm{kg}$ for the equivalent PAHs (NAP, ACE, ANT, PHE \& PYR). This supports the hypothesis that the petrolic compounds of the pitch lake influence the relatively high levels of PAHs in the soils neighbouring the La Brea pitch lake. 
Examining the Soils Adjacent to the Historical Pitch Lake for Levels of Polycyclic Aromatic Hydrocarbons (Pahs) and Naturally Occurring Pah-Degrading Bacteria

Analysis of the results showed that NAP ( $58 \%$ of $\Sigma 5 \mathrm{PAHs}$ ) was the most dominant among the five PAH followed by PHE, ACE, ANT,and PYR (20\%, 13\%, 4.0\% and 3.8\%, respectively). (Wilcke et al., 1999)observed a similar abundance pattern for the natural soils of the tropical Brazilian forest in the Amazon basin with the order of abundance being: NAP $>$ PHE $>$ ACE $>$ PYR $\approx$ ANT. Interestingly the dominant PAHs in the Amazon forest were also NAP ( $~ 56 \%$ of total PAHs) and PHE ( $\sim 21 \%$ of total PAHs) which showed similar ratios to that found in the pitch lake soils. In temperate regions, PYR tended to be the most dominant of the five selected PAHs (Bucheli et al., 2004; Kulakow \& Erickson, 2000)of the five selected PAHs chosen in this study, regardless of land use. A possible explanation purported by (Wilcke et al., 1999)is that the tropics have biological processes that contribute to the relatively high NAP and PHE concentrations in the soils.

Table3. Soil polycyclic aromatic hydrocarbon (PAH) concentrations compiled from literature data as compared to those determined in this study.

\begin{tabular}{|c|c|c|c|c|c|}
\hline Country & Land use & $\begin{array}{l}\Sigma P A H \\
\text { concentration } \\
\text { (mg/kg dry } \\
\text { wt.) }\end{array}$ & $\begin{array}{l}\text { Number } \\
\text { of PAHs }\end{array}$ & PAH abundance & Reference \\
\hline Brazil & Rural & 0.10 & 20 & $\begin{array}{l}\text { Nap }>\text { Phe }>\text { Per }> \\
\text { Pyr } \approx \text { Fla }\end{array}$ & Wilcke et al. (2003) \\
\hline UK & Rural & 0.19 & 12 & ND & Wild and Jones (1995) \\
\hline Germany & Rural & 1.90 & 6 & ND & Tebaay et al. (1993) \\
\hline India & Rural & 6.70 & 11 & $\mathrm{Chr}>\mathrm{BbF}>\mathrm{Fla}$ & Masih and Taneja (2006) \\
\hline Switzerland & Urban & $0.40-0.62$ & 16 & Fla $>$ Pyr $>$ Chr $>$ Phe & Bucheli et al. (2004) \\
\hline Germany & Industrial & 16.00 & 6 & & Tebaay et al. (1993) \\
\hline UK & Industrial & 4.50 & 12 & $\mathrm{Fla}>\mathrm{BaA}+(\mathrm{C}+\mathrm{T})$ & Wild and Jones (1995) \\
\hline Iran & Industrial & $100-10000$ & $5-20$ & ND & Arbabi et al. (2004) \\
\hline Austria & Industrial & $0.28-79.00$ & 18 & ND & Weiss et al. (1994) \\
\hline USA & Industrial & $34-781$ & 16 & Flo $\approx \mathrm{Pyr}>\mathrm{Phe}>\mathrm{Chr}$ & $\begin{array}{l}\text { Kulakow and Erickson } \\
(2000)\end{array}$ \\
\hline South Africa & Industrial & $>30,000$ & 9 & $\begin{array}{l}\text { Phe }>\text { Fla }>\text { Pyr }>\text { Nap } \\
>\text { Chr }\end{array}$ & Atagana, 2004 \\
\hline India & Industrial & $13.70-28.50$ & 11 & Chr $>$ Fla $>$ BbF & Masih and Taneja (2006) \\
\hline Trinidad & Rural & $16.04-127.37$ & 5 & $\begin{array}{l}\text { Nap }>\text { Phe }>\text { Ace }> \\
\text { Pyr } \approx \text { Ant }\end{array}$ & This study \\
\hline
\end{tabular}

Ace: acenaphthene, Ant: anthracene, BaA: Benzo[a]anthracene, BbF: Benzo[b]fluoranthene, Chr: chrysene, Fla: fluoranthene, Flo: fluorine, Nap: naphthalene, Per: perylene, Phe: phenanthrene, Pyr: pyrene, ND: no dataModified from (Masih \& Taneja, 2006) 
Examining the Soils Adjacent to the Historical Pitch Lake for Levels of Polycyclic Aromatic Hydrocarbons (Pahs) and Naturally Occurring Pah-Degrading Bacteria
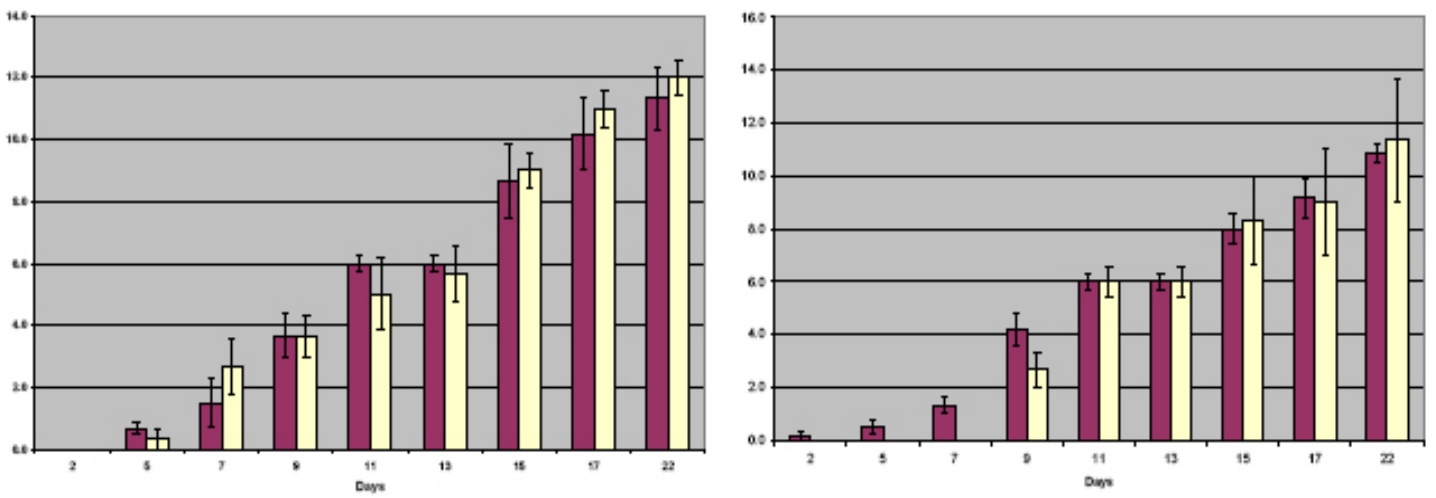

\section{PHENANTHRENE}

\section{ANTHRACENE}
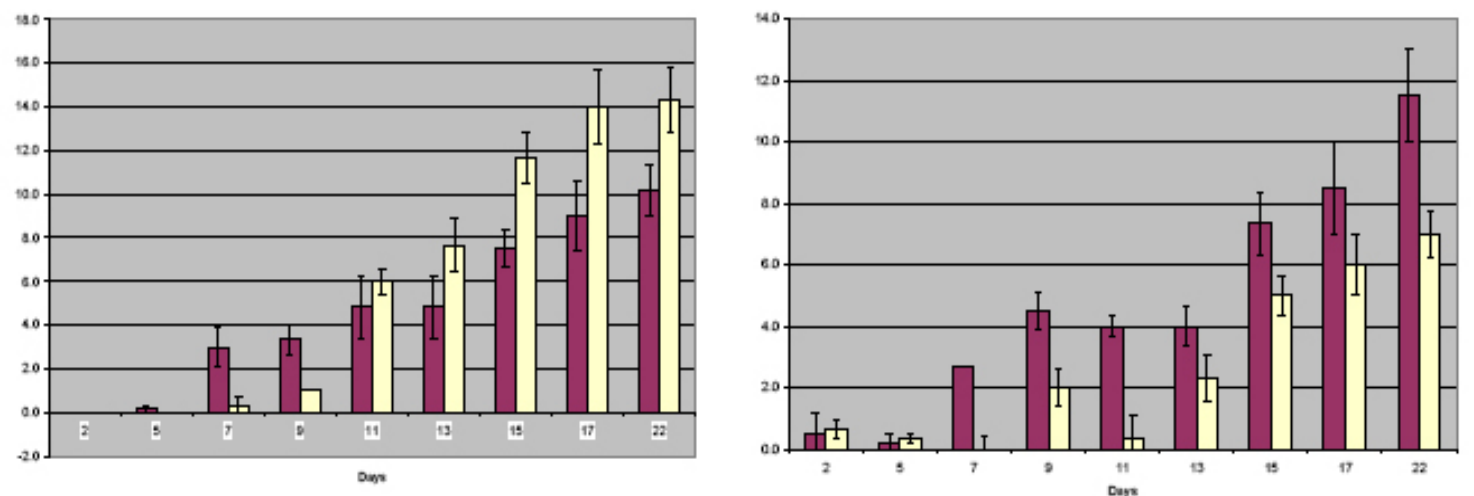

\section{PYRENE}

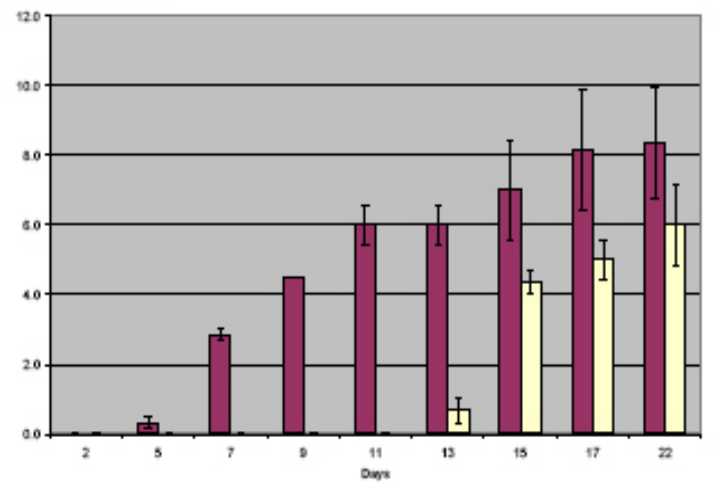

\section{Legend}

High Impact Soil (HIS) - within $400 \mathrm{~m}$ from the perimeter of the Pitch Lake

Low Impact Soil (LIS) - more than $500 \mathrm{~m}$ from the perimeter of the Pitch Lake

Fig3. Changes in the mean number of bacterial clear zones formed for the HIS and LIS in each PAH enriched medium over a 22-day period

The ANOVA of results showed that the level of $\sum 5$ PAHs was significantly $(\mathrm{p}<0.05)$ lower in Zone 3 compared to Zones 1 and 2. Such that the soil samples from these two zones were grouped, and collectively referred to as the High Impact Soils (HIS) and the soil samples from Zone 3 was separately referred to as the Low Impact Soils (LIS).

For the PAH-degrading bacteria, the lower molecular weight PAHs (NAP and ACE), showed no notable differences in the number of clear zones formed (an indicator of PAH utilization) in either the High Impact Soils (HIS - within 400m of the Pitch Lake) and the Low Impact Soils (LIS - more than 500m away from the 
Examining the Soils Adjacent to the Historical Pitch Lake for Levels of Polycyclic Aromatic Hydrocarbons (Pahs) and Naturally Occurring Pah-Degrading Bacteria

Pitch Lake) by bacterial colonies over a 22-day period (Figure 2). However, as the aqueous solubility and recalcitrance to biodegradation increased of the PAHs, so does the number of bacterial clear zones formed in the HIS compared to the LIS (PHE, ANT and PYR). This supports the thought that PAH degraders exist in most soils as a normal part of the soils flora. However, for the higher molecular weight PAHs like (PHE, ANT and PYR) we note that the higher number of clear zones were seen in the HIS, suggesting that for the isolation of bacteria capable of degrading more complex PAHs, tends to be associated with a higher PAH impacted soil.

It was noted that the levels of the total PAHs ( $\Sigma 5 \mathrm{PAHs}$ ) were not significantly different from each other in Zones 1 and 2 (Table 2), so that soil samples from these two zones were grouped, and collectively referred to as the High Impact Soils (HIS). The ANOVA of results showed that the level of $\sum 5$ PAHs was significantly $(p<0.05)$ lower in zone 3 compared to zones 1 and 2 . Thus, the soil samples from zone 3 were separately referred to as the Low Impact Soils (LIS).

For the lower molecular weight PAHs (NAP and ACE), there were no notable differences in the number of clear zones formed (an indicator of PAH utilization) in either the High Impact Soils (HIS - within 400m of the Pitch Lake) and the Low Impact Soils (LIS - more than $500 \mathrm{~m}$ away from the Pitch Lake) by bacterial colonies over a 22-day period. However, as the aqueous solubility and recalcitrance to biodegradation increases for the PAHs so does the number of bacterial clear zones formed in the HIS compared to the LIS (PHE, ANT,and PYR). This supports the thought that PAH degraders exist in most soils as a normal part of the soils flora. However, for the higher molecular weight PAHs like (PHE, ANT,and PYR) we note that more clear zones are seen in the HIS, suggesting that for the isolation of bacteria capable of degrading more complex PAHs, tends to be associated with a PAH impacted soil.

\section{Concluding Remarks}

Our results showed that the levels for most of the individual and total PAHs were generally above the acceptable limits, even in the reference zone ( $>500 \mathrm{~m}$ away from the pitch lake). The La Brea Pitch Lake also seemed to influence the levels of NAP in its surrounding soils as is observed by a progressive decrease in concentration, as distance increased from the homogenous source of PAHs (La Brea Pitch Lake). This is further supported by trends in the general decrease in the levels of PHE, ACE,and ANT as proximity increased from the La Brea Pitch Lake. Also, that the lack of significant difference among zones may be due to the high standard error associated with the sample means for the majority of parameters measured and this may be attributed to the presence of pitch dykes ("veins"), which may have skewed the levels of the physicochemical parameters tested.

\section{REFERENCES}

1. Amellal, N., Portal, J.-M., Vogel, T. \& Berthelin, J. (2001). Distribution and location of polycyclic aromatic hydrocarbons (PAHs) and PAH-degrading bacteria within polluted soil aggregates. Biodegradation12, 49-57.

2. Bucheli, T. D., Blum, F., Desaules, A. \& Gustafsson, Ö. (2004). Polycyclic aromatic hydrocarbons, black carbon, and molecular markers in soils of Switzerland. Chemosphere56, 1061-1076.

3. Cerniglia, C. E. (1992). Biodegradation of polycyclic aromatic hydrocarbons. Biodegradation3, 351-368.

4. Chaitan, W. B. \& V.R.Graterol (1992). A gravity investigation of the Pitch Lake of Trinidad and Tobago. Transactions of the 2nd Geological Conference of the Geological Society of Trinidad and Tobago (GSTT), 50.

5. ECRC, E. C. R. C.-. (2003). Standard operating procedure for petroleum contaminated soils.

6. Harmsen, J. (2004). Land farming of Polycyclic Aromatic Hydrocarbons and Mineral Oil contaminated sediments. In PhD Thesis. Wageningen University, Wageningen, the Netherlands.

7. Juhasz, A. L., Britz, M. L., Stanley, G. A. \& G, A. S. (1997). Degradation of fluoranthene, pyrene, benz[ a ]anthracene and dibenz[ a , h ]anthracene by Burkholderia cepacia. Journal of Applied Microbiology83, 189-198. 
Examining the Soils Adjacent to the Historical Pitch Lake for Levels of Polycyclic Aromatic Hydrocarbons (Pahs) and Naturally Occurring Pah-Degrading Bacteria

8. Kiyohara, H., Nagao, K. \& Yana, K. (1982). Rapid Screen for Bacteria Degrading Water-Insoluble, Solid Hydrocarbons on Agar Plates. Appl Environ Microbiol43, 454-457.

9. Kugler, H. G. (1965). Sediments volcanism. In Transactions of the fourth Caribbean Geological Conference, pp. 11-14. Edited by J. B. Saunders. POS, Trinidad and Tobago: Caribbean Printers.

10. Kulakow, P. A. \& Erickson, L. (2000). A nationwide field test of petroleum-contaminated soils. In Proceedings of the 2000 Conference on Hazardous Waste Research. Denver, Colorado.

11. LATT, L. A. o. T. a. T. L.-. (2004).La Brea, Trinidad.

12. Lehmann, V. (1998). Bioremediation: A solution for polluted soils in the South? .Biotechnology and Development Monitor34, 12-17.

13. Lijzen, J. P. A., Baars, A. J., Otte, P. F., Rikken, M. G. J., Swartjes, F. A., Verbruggen, E. M. J. \& Wezel, A. P. (2001). Technical evaluation of the Intervention Values for Soil/sediment and Groundwater; Human and ecotoxicological risk assessment and derivation of risk limits for soil, aquatic sediment and groundwater. In RIVM report 711701023.

14. Masih, A. \& Taneja, A. (2006). Polycyclic aromatic hydrocarbons (PAHs) concentrations and related carcinogenic potencies in soil at a semi-arid region of India. Chemosphere65, 449-456.

15. Mohammed, A. (2000). Cellular, histopatholoogical and molecular responses of Corbula caribea (Mollusca, Bivalvia) from a natural oil seep, to field and/or experimental exposure to Polycyclic Aromatic Hydrocarbons. In $P h D$ Thesis. University of the West Indies, St. Augustine.

16. Mohammed, A. \& Agard, J. (2004). The occurrence of NADPH-ferrihemoprotein reductase in Corbula caribea, from a natural oil seep at La Brea, Trinidad. Marine Pollution Bulletin48, 784-789.

17. Mueller, J. G., Cerniglia, C. E. \& Pritchard, P. H. (1996). Bioremediation of petroleum contamination. New York: Cambridge University Press.

18. Stieber, M., Werner, P. \& Frimmel, F. H. (1994). Investigations on the microbial degradation of polycyclic aromatic hydrocarbons in contaminated soils. Boca Raton, Florida. : CRC Press.

19. Wilcke, W., Müller, S., Kanchanakool, N., Niamskul, C. \& Zech, W. (1999). Polycyclic aromatic hydrocarbons in hydromorphic soils of the tropical metropolis Bangkok. Geoderma91, 297-309.

20. Wilcke, W. (2000). SYNOPSIS Polycyclic Aromatic Hydrocarbons (PAHs) in Soil - a Review. Journal of Plant Nutrition and Soil Science163, 229-248.

21. Wilcke, W., Amelung, W., Krauss, M., Martius, C., Bandeira, A. \& Garcia, M. (2003). Polycyclic aromatic hydrocarbon (PAH) patterns in climatically different ecological zones of Brazil. Organic Geochemistry34, 1405-1417.

Citation: Amalia Hosein, Azad Mohammed, Pathmanathan Umaharan, Adesh Ramsubhag, “Examining the Soils Adjacent to the Historical Pitch Lake for Levels of Polycyclic Aromatic Hydrocarbons (Pahs) and Naturally Occurring Pah-Degrading Bacteria". American Research Journal of Earth Science; vol 1, no. 1, pp. 56-64.

Copyright (c) Amalia Hosein, Azad Mohammed, Pathmanathan Umaharan, Adesh Ramsubhag. This is an open access article distributed under the Creative Commons Attribution License, which permits unrestricted use, distribution, and reproduction in any medium, provided the original work is properly cited. 